\title{
Evaluation of the Obesity Genes FTO and MC4R and the Type 2 Diabetes Mellitus Gene TCF7L2 for Contribution to Stroke Risk: The Mannheim-Heidelberg Stroke Study
}

\author{
Yaroslav Winter ${ }^{\mathrm{a}}$ Tobias Back $^{\mathrm{b}} \quad$ André Scherag $^{\mathrm{c}} \quad$ Jakob Linseisen $^{\mathrm{d}, \mathrm{e}} \quad$ Sabine Rohrmann $^{\mathrm{d}}$ \\ Oliver Lanczik ${ }^{f}$ Anke Hinney ${ }^{g}$ Susann Scherag ${ }^{g} \quad$ Michael Neumaier $^{h} \quad$ Peter A. Ringleb $^{i}$ \\ Richard Dodel $^{\mathrm{a}}$ Johannes Hebebrand ${ }^{\mathrm{g}}$ \\ ${ }^{\text {a }}$ Department of Neurology, Philipps University Marburg, \\ ${ }^{\mathrm{b}}$ Department of Neurology, Saxon Hospital Arnsdorf, Arnsdorf/Dresden, \\ 'Institute for Medical Informatics, Biometry and Epidemiology, University of Duisburg-Essen, Essen, \\ ${ }^{\mathrm{d}}$ Division of Cancer Epidemiology, German Cancer Research Center, Heidelberg, \\ ${ }^{\mathrm{e}}$ Institute of Epidemiology, Helmholtz Center Munich, Neuherberg, \\ ${ }^{f}$ Department of Neurology, Klinikum Mannheim, University of Heidelberg, \\ ${ }^{9}$ Department of Child and Adolescent Psychiatry, University of Duisburg-Essen, Essen, \\ ${ }^{\mathrm{h}}$ Institute for Clinical Chemistry, Klinikum Mannheim, \\ i Department of Neurology, Klinikum Heidelberg, University of Heidelberg, Germany
}

\section{Keywords}

Genetics · Obesity genes · FTO - MC4R - TCF7L2 - Stroke

\section{Summary}

Objective: Studies evaluating genetic markers for vascular risk and risk of stroke are limited, and none of them evaluated obesity genes. The objective was to investigate the genetic markers related to obesity genes FTO and MC4R and the gene of type 2 diabetes mellitus TCF7L2 for their contribution to risk of stroke and transient ischemic attacks (TIA). Methods: We recruited 379 consecutive patients with stroke/TIA and 379 healthy population-based controls. The single-nucleotide polymorphisms (SNPs) rs9937053 (FTO), rs2229616 (MC4R V103l), rs17782313 (188kb downstream of MC4R), and rs7903146 (TCF7L2) were evaluated for association with stroke using logistic regression analyses. Results: The odds ratios for stroke/TIA were $1.14(95 \% \mathrm{Cl} 0.91-1.42)$ for rs9937053/FTO, 1.11 (95\%Cl 0.49-2.51) for rs2229616/ MC4R, $1.05(95 \% \mathrm{Cl} 0.82-1.3)$ for rs $17782313 / M C 4 R$, and $0.99(95 \% \mathrm{Cl} 0.78-1.25)$ for rs7903146/TCF7L2. Further exploration revealed that male patients with the $\mathrm{T}$ allele of rs7903146/TCF7L2 had a worse clinical outcome compared with male patients carrying the $\mathrm{C}$ allele. Conclusion: The observed trends of obesity risk alleles for risk of stroke/TIA as well as the possible sex-specific differences in clinical outcomes found for the TCF7L2 (rs7903146) require replication in future studies. Our study demonstrates that candidate gene studies for common stroke may benefit from focusing on polymorphisms that predispose to vascular risk.

\section{Introduction}

Stroke is the third leading cause of death in adults in the Western world. It imposes a significant economic burden on the society and individual patients [1-5]. The two principal types of stroke are ischemic and hemorrhagic stroke. Both are associated with vascular risk factors such as chronic arterial hypertension, type 2 diabetes mellitus (T2DM), hyperlipidemia, and obesity [6-8]. Studies in twins, families, and animal models support the role of genetic factors in the etiology of stroke [9]. However, the extent of genetic contribution to the risk of stroke is uncertain.

Mendelian disorders associated with stroke include metabolic disorders of inborn origin, hemoglobinopathies, dyslipoproteinemias, and cardioembolic disorders. Examples of such are sickle cell disease, cerebral autosomal dominant arteriopathy with subcortical infarct and leukoencephalopathy (CA-

\section{KARGER \\ Fax +497614520714 \\ Information@Karger.de}

www.karger.com (c) 2011 S. Karger GmbH, Freiburg

$1662-4025 / 11 / 0044-0290 \$ 38.00 / 0$

Accessible online at:

www.karger.com/ofa
Prof. Dr. med. Tobias Back

Department of Neurology, Saxon Hospital Arnsdorf

Hufelandstraße 15, 01477 Arnsdorf/Dresden, Germany

Tel. +49 35200 263-511, Fax -513

tobias.back@skhar.sms.sachsen.de 
DASIL), mitochondrial disorders such as mitochondrial encephalopathy with lactic acidosis and stroke-like episodes (MELAS), familial atrial myxoma, and Fabry's disease [9]. However, all these well recognized and phenotypically distinct causes for stroke include only a small minority of stroke cases.

Defining the genetic basis of common stroke, which is thought to have a polygenic basis, has proven more challenging [10]. Most genetic studies which evaluated candidate genes in common stroke focused on genes involved in thrombosis and coagulation [10]. The majority of these candidate genes were evaluated initially in ischemic heart disease. Genes involved in the biology of well-known risk factors for stroke (e.g. arterial hypertension, hyperlipidemia, T2DM, and obesity) have received limited attention. To the best of our knowledge, studies evaluating the role of candidate genes of obesity in the formation of stroke are lacking to date. Data on the relation of T2DM genes with stroke are scarce and inconsistent $[11,12]$.

The objective of the Mannheim-Heidelberg Stroke Study was to evaluate confirmed genetic markers of the obesity genes 'fat mass and obesity associated' (FTO) and the 'melanocortin 4 receptor' $(M C 4 R)$ as well as the T2DM susceptibility gene 'transcription factor 7-like 2' (TCF7L2) for their contribution to the risk of stroke and transient ischemic attacks (TIAs). The phenotype analysis of the study population had shown a positive association between anthropometric measures of obesity and increased risk of stroke/TIA [8].

\section{Patients and Methods}

\section{Study Design}

The Mannheim-Heidelberg Stroke Study is a case-control genetic study of the disease-oriented Genome Network 'Obesity and Related Disorders', which is a part of the German National Genome Research Network plus $\left(\mathrm{NGFN}^{\text {plus }}\right)$. For a detailed description of the study design, we refer to our previous publication [8]. In brief, the study sample consisted 379 consecutive cases of stroke and TIAs and 379 healthy controls. Cases were recruited in the Departments of Neurology of the University Hospitals of Mannheim and Heidelberg between February 1, 2005 and January 31,2006 . Those patients with recurrent cerebrovascular events or a history of cerebrovascular events prior to initiation of the study were not excluded. Clinical records were incomplete for 22 out of 401 initially recruited cases so that these cases were excluded from the analysis. Regional controls without a history of cerebrovascular disease were frequency-matched for age and sex using the database of 25,540 participants of the population-based cohort EPIC-Heidelberg [13]. For control selection, we draw individuals from the following age groups: $<50,50-55$, $56-60,61-65,66-70$, and $>70$ years. Note that the age range for the cases was between 25 and 90 years, whereas the age range of controls was between 45 and 75 years only. The study was approved by the local ethics committee, and all participants gave informed consent. Thus, patients with impaired conciousnes or severe aphasia had to be excluded because no informed consent could be obtained in those instances.

\section{Clinical Evaluation}

Each patient received a complete medical and neurological examination, $\mathrm{CT}$ and/or MRI of the head. The diagnosis of stroke was defined according to the World Health Organization (WHO) [14]. The following markers of obesity were evaluated in less than $48 \mathrm{~h}$ after admission: BMI, waist-to-hip ratio (WHR), waist circumference, and waist-to-stature ratio (WSR). BMI was calculated as weight (kilograms) divided by height (meters squared). WHR was calculated as waist divided by hip circumference. Waist circumference $(\mathrm{cm})$ was measured at the level of the umbilicus. Hip circumference $(\mathrm{cm})$ was measured at the level of the bilateral greater trochanters. WSR was defined as waist circumference divided by body height. The vascular risk factors included T2DM (fastening blood glucose $\geq 126 \mathrm{mg} / \mathrm{dl}$ or use of insulin or oral hypoglycemic agents), hypertension (systolic blood pressure $\geq 140 \mathrm{~mm} \mathrm{Hg}$ and/or diastolic blood pressure $\geq 90 \mathrm{~mm} \mathrm{Hg}$ or treatment with antihypertensive agents), hyperlipidemia (total serum cholesterol level $\geq 240 \mathrm{mg} / \mathrm{dl}$ or use of antihyperlipidemic agents), and physical inactivity (sport activities of less than $20 \mathrm{~min} 2$ times per week).

Clinical outcomes were measured using the National Institute of Health Stroke Scale (NIHSS) and modified Rankin scale (mRS), which are valid and reliable measures of stroke outcome $[15,16]$. The NIHSS is a standardized measure of stroke severity and level of stroke impairment. It is one of the most frequently used scales in stroke clinical trials. The NIHSS scores range from 0 to 42 , with increasing scores indicating increasing stroke severity [16]. The mRS is a measure of the functional status and disability. Its scores range from 0 (no impairment) to 5 (severe impairment) [15].

\section{Genotyping}

The following single nucleotide polymorphisms (SNPs) were used in the analysis: rs17782313 (MC4R, obesity risk allele C) [17], rs2229616 (MC4R V103I, obesity risk allele A) [18], rs9937053 (FTO, obesity risk allele A) [19], rs7903146 (TCF7L2, T2DM risk allele T) [20].

The rationale for use of these SNPs in the analysis was based on following: The association of the common genetic variants of FTO and $M C 4 R$ with BMI was shown in large-scale genetic studies [17, 19, 21]. The $M C 4 R$ SNP rs17782313 is in high linkage disequilibrium with a SNP that is associated with waist circumference and insulin resistance [21]. The TCF7L2 polymorphism rs7903146 is associated with T2DM; interestingly, this major T2DM risk allele is also weakly negatively associated with obesity [22]. Recently, the rs $7903146 \mathrm{~T}$ allele has been shown to be associated with severity and mortality of coronary artery disease [23].

Genomic DNA was isolated from EDTA-anticoagulated blood using standard procedures. The FTO SNP rs9939609 and the TCF7L2 SNP rs79031746 were genotyped using tetra-ARMS-PCR as described previously [24, 25]. For MC4R rs2229616 (V103I) DNA samples were genotyped as described previously [26], and rs17782313 was genotyped using TaqMan ${ }^{\circledR}$ SNP genotyping assay C_32667060_10 (Applied Biosystems, Darmstadt, Germany) with standard conditions; call rates were $\geq 99 \%$, with $100 \%$ concordance of duplicates.

\section{Statistical Analysis}

All genotype distributions (in cases, controls and in the sex-stratified subsamples) were tested for deviations from Hardy-Weinberg equilibrium using the PLINK software (Version 1.04), and no evidence for such deviations was detected (all $\mathrm{p}>>0.12$ ). All phenotypes were analyzed by either linear or logistic regression analyses (crude (model 1 in table 3 ) and (simultaneously; model 2 in table 3 ) adjusted for the covariates age (years), sex (female/male), history of hypertension (yes/no), history of diabetes (yes/no), physical inactivity (yes/no), and smoking (yes/no)). Except for MC4R (rs2229616), where a dominant mode of inheritance was assumed, each SNP was analyzed under an (log-)additive genetic model. Power calculations were done with the software QUANTO (Version 1.2.3, http://hydra.usc.edu/gxe). 379 case-control pairs were estimated to yield a power of $83 \%$ to detect log-additive odds ratios (ORs) of 1.4 for a minor allele frequency of $25 \%$ (based on HapMap CEU data for rs7903146) and $\alpha=0.05$ (two-sided). Confidence intervals were calculated with coverage of $95 \%$ (abbreviated $95 \%$ CI), and accordingly the level $\alpha$ for each test was 0.05 (two-sided). Unless otherwise stated, all reported $\mathrm{p}$ values are nominal, two-sided, and not adjusted for multiple testing. 
Table 1. Demographics, clinical features of the study samples stratified by sex

\begin{tabular}{|c|c|c|c|c|c|c|c|c|c|c|}
\hline & \multicolumn{5}{|l|}{ Men } & \multicolumn{5}{|l|}{ Women } \\
\hline & \multicolumn{2}{|l|}{$\begin{array}{l}\text { controls } \\
(\mathrm{n}=238)\end{array}$} & \multicolumn{2}{|l|}{$\begin{array}{l}\text { cases } \\
(n=238)\end{array}$} & \multirow[t]{2}{*}{$\mathrm{p}$ value } & \multicolumn{2}{|l|}{$\begin{array}{l}\text { controls } \\
(\mathrm{n}=141)\end{array}$} & \multicolumn{2}{|l|}{$\begin{array}{l}\text { cases } \\
(\mathrm{n}=141)\end{array}$} & \multirow[t]{2}{*}{$\mathrm{p}$ value } \\
\hline & mean $\pm \mathrm{SD}$ & $\%$ yes & mean $\pm \mathrm{SD}$ & $\%$ yes & & mean $\pm \mathrm{SD}$ & $\%$ yes & mean $\pm \mathrm{SD}$ & $\%$ yes & \\
\hline Age, years & $65.0 \pm 9.0$ & & $66.9 \pm 10.9$ & & 0.018 & $65.0 \pm 9.0$ & & $68.0 \pm 14.1$ & & 0.021 \\
\hline Weight, kg & $84.4 \pm 12.0$ & & $84.7 \pm 12.7$ & & 0.934 & $69.9 \pm 11.1$ & & $74.8 \pm 18.4$ & & 0.071 \\
\hline Height, $\mathrm{cm}$ & $175.3 \pm 6.6$ & & $173.9 \pm 7.1$ & & 0.016 & $161.5 \pm 6.2$ & & $161.7 \pm 6.4$ & & 0.580 \\
\hline $\mathrm{WC}, \mathrm{cm}$ & $98.5 \pm 10.3$ & & $103.6 \pm 11.1$ & & $<0.001$ & $85.0 \pm 11.2$ & & $98.2 \pm 15.5$ & & $<0.001$ \\
\hline $\mathrm{HC}, \mathrm{cm}$ & $102.5 \pm 6.4$ & & $103.5 \pm 10.6$ & & 0.336 & $102.7 \pm 8.3$ & & $105.3 \pm 12.1$ & & 0.104 \\
\hline WHR & $1.0 \pm 0.7$ & & $1.00 \pm 0.08$ & & $<0.001$ & $0.8 \pm 0.8$ & & $0.93 \pm 0.1$ & & $<0.001$ \\
\hline BMI & $27.5 \pm 3.6$ & & $28.0 \pm 3.7$ & & 0.121 & $26.8 \pm 4.3$ & & $28.6 \pm 6.5$ & & 0.087 \\
\hline WSR & $0.52 \pm 0.08$ & & $0.60 \pm 0.07$ & & $<0.001$ & $0.52 \pm 0.08$ & & $0.61 \pm 0.10$ & & $<0.001$ \\
\hline PIN & & 44.0 & & 82.5 & $<0.001$ & & 41.8 & & 87.2 & $<0.001$ \\
\hline AHTN & & 49.0 & & 84.3 & $<0.001$ & & 49.6 & & 80.4 & $<0.001$ \\
\hline $\mathrm{T} 2 \mathrm{DM}$ & & 11.9 & & 30.9 & $<0.001$ & & 9.5 & & 30.7 & $<0.001$ \\
\hline HLP & & 55.6 & & 50.4 & 0.087 & & 56.0 & & 53.9 & 0.322 \\
\hline
\end{tabular}

AHTN = Arterial hypertension; HC = hip circumference; HLP = hyperlipidemia; PIN = physical inactivity; WC = waist circumference .

*Descriptive two-sided p value of the Wilcoxon-Mann-Whitney test.

Table 2. Genotype distributions in cases and controls

\begin{tabular}{|c|c|c|c|c|c|c|c|}
\hline \multirow[t]{2}{*}{ SNP (gene) } & \multirow[t]{2}{*}{ Genotypes } & \multicolumn{3}{|l|}{ Men } & \multicolumn{3}{|l|}{ Women } \\
\hline & & $\begin{array}{l}\text { number of } \\
\text { cases (\%) }\end{array}$ & $\begin{array}{l}\text { number of } \\
\text { controls (\%) }\end{array}$ & $\mathrm{p}$ value* & $\begin{array}{l}\text { number of } \\
\text { cases }(\%)\end{array}$ & $\begin{array}{l}\text { number of } \\
\text { controls (\%) }\end{array}$ & $\mathrm{p}$ value* \\
\hline \multirow[t]{3}{*}{ rs9937053 (FTO) } & AA & 33 (16.4) & $40(17.3)$ & 0.26 & $20(16.9)$ & $19(14.0)$ & 0.73 \\
\hline & AT & $104(51.7)$ & $102(44.2)$ & & $64(54.2)$ & $73(53.7)$ & \\
\hline & $\mathrm{TT}$ & $64(31.8)$ & $89(38.5)$ & & $34(28.8)$ & $44(32.4)$ & \\
\hline \multirow[t]{3}{*}{ rs17782313 (MC4R) } & $\mathrm{CC}$ & $12(6.0)$ & $15(6.6)$ & 0.87 & $10(8.5)$ & $4(3.0)$ & 0.18 \\
\hline & CT & $78(38.9)$ & $92(40.7)$ & & $46(40.0)$ & $53(39.9)$ & \\
\hline & TT & $111(55.1)$ & $119(52.7)$ & & $62(52.5)$ & $76(57.1)$ & \\
\hline \multirow[t]{2}{*}{ rs2229616 (MC4R) } & GG & $205(96.7)$ & $226(96.6)$ & 1.00 & $121(96.0)$ & $136(97.1)$ & 0.74 \\
\hline & GA & $7(3.3)$ & $8(3.4)$ & & $5(4.0)$ & $4(2.9)$ & \\
\hline \multirow[t]{2}{*}{ rs7903146 (TCF7L2) } & $\mathrm{CC}$ & $108(50.9)$ & $114(49.1)$ & 0.92 & $60(47.6)$ & $69(50.7)$ & 0.71 \\
\hline & $\mathrm{TT}$ & $17(8.0)$ & $18(7.8)$ & & $8(6.3)$ & $11(8.1)$ & \\
\hline
\end{tabular}

*Descriptive two-sided $\mathrm{p}$ value of Fishers exact test.

\section{Results}

We included 379 cases with stroke (ischemic stroke $\mathrm{n}=301$, intracerebral hemorrhage $(\mathrm{ICH}) \mathrm{n}=37$, or TIA $n=41$ ) of whom 141 were female (37.2\%). Demographics and distribution of known vascular risk factors are shown in table 1. Due to the fact that among the controls no individual was older than 75 years, the mean age of cases was slightly higher than the mean age of controls $(67.3 \pm 12.2$ vs. $65.0 \pm 8.3$ years; $\mathrm{p}=0.02)$. Cases had higher prevalences of obesity $(29.8 \%$ of cases $(\mathrm{n}=113)$ vs. $20.8 \%$ of controls $(\mathrm{n}=79) ; \mathrm{p}<0.01)$ and other vascular risk factors than controls. The mean NIHSS score at admission was $4.5 \pm 3.9$ (median 3 ) in male patients and $5.1 \pm 4.5$ (median 4 ) in female patients.

The genotype frequencies in cases and controls are shown in table 2. The T allele of TCF7L2 showed a positive association with T2DM (OR 1.35, 95\% CI 1.02-1.80), which remained significant after adjustment for age, sex , and vascular risk factors (OR 1.36, 95\% CI 1.01-1.84). For all other markers, though not statistically detectable, we observed similar directions of allelic effects for BMI and WHR as reported previously (e.g. increased BMI (regression coefficient 0.15, 
Table 3. ORs for the associations between genotype and risk of stroke/TIA

\begin{tabular}{|c|c|c|c|c|c|c|c|c|}
\hline \multirow[t]{2}{*}{ SNP (gene) } & \multirow[t]{2}{*}{ Effect allele } & \multirow[t]{2}{*}{ Genetic model } & \multicolumn{3}{|c|}{ Model 1* } & \multicolumn{3}{|c|}{ Model 2** } \\
\hline & & & OR & $95 \% \mathrm{CI}$ & $\mathrm{p}$ value & OR & $95 \% \mathrm{CI}$ & $\mathrm{p}$ value \\
\hline \multicolumn{9}{|l|}{ All participants } \\
\hline rs9937053 (FTO) & A & $\mathrm{ADD}$ & 1.14 & $0.91-1.42$ & 0.25 & 1.11 & $0.85-1.44$ & 0.46 \\
\hline rs17782313 (MC4R) & $\mathrm{C}$ & ADD & 1.05 & $0.82-1.34$ & 0.72 & 1.06 & $0.79-1.42$ & 0.68 \\
\hline rs2229616 (MC4R) & A & DOM & 1.11 & $0.49-2.51$ & 0.80 & 0.80 & $0.31-2.08$ & 0.64 \\
\hline rs7903146 (TCF7L2) & $\mathrm{T}$ & $\mathrm{ADD}$ & 0.99 & $0.78-1.25$ & 0.92 & 0.85 & $0.64-1.13$ & 0.26 \\
\hline \multicolumn{9}{|l|}{ Males } \\
\hline rs9937053 (FTO) & A & $\mathrm{ADD}$ & 1.13 & $0.86-1.48$ & 0.39 & 1.1 & $0.79-1.52$ & 0.58 \\
\hline rs17782313 (MC4R) & $\mathrm{C}$ & ADD & 0.92 & $0.67-1.25$ & 0.59 & 0.90 & $0.63-1.31$ & 0.61 \\
\hline rs2229616 (MC4R) & A & DOM & 0.96 & $0.34-2.71$ & 0.95 & 0.53 & $0.16-1.74$ & 0.29 \\
\hline rs7903146 (TCF7L2) & $\mathrm{T}$ & $\mathrm{ADD}$ & 0.96 & $0.72-1.29$ & 0.80 & 0.82 & $0.58-1.17$ & 0.28 \\
\hline \multicolumn{9}{|l|}{ Females } \\
\hline rs9937053 (FTO) & A & ADD & 1.16 & $0.80-1.69$ & 0.43 & 1.16 & $0.73-1.84$ & 0.54 \\
\hline rs17782313 (MC4R) & $\mathrm{C}$ & $\mathrm{ADD}$ & 1.32 & $0.87-2.00$ & 0.19 & 1.38 & $0.83-2.28$ & 0.21 \\
\hline rs2229616 (MC4R) & A & DOM & 1.41 & $0.37-5.35$ & 0.62 & 1.74 & $0.32-9.60$ & 0.52 \\
\hline rs7903146 (TCF7L2) & $\mathrm{T}$ & ADD & 1.04 & $0.70-1.53$ & 0.86 & 0.9 & $0.56-1.46$ & 0.68 \\
\hline
\end{tabular}

$\mathrm{ADD}=$ Additive mode of inheritance DOM $=$ dominant mode of inheritance.

*Model 1: not adjust; crude estimates.

**Model 2: simultaneously adjusted for age (years) and sex (female/male), history of hypertension (yes/no), history of diabetes (yes/no), physical inactivity (yes/no) and smoking (yes/no).

Table 4. Associations between genotype and risk of different cerebrovascular events

\begin{tabular}{|c|c|c|c|c|c|c|c|c|}
\hline \multirow[t]{2}{*}{ SNP (gene) } & \multirow[t]{2}{*}{ Effect allele } & \multirow[t]{2}{*}{ Genetic model } & \multicolumn{3}{|c|}{ Model 1* } & \multicolumn{3}{|c|}{ Model 2** } \\
\hline & & & OR & $95 \% \mathrm{CI}$ & $\mathrm{p}$ value & OR & $95 \% \mathrm{CI}$ & $\mathrm{p}$ value \\
\hline \multicolumn{9}{|l|}{$T I A$} \\
\hline rs9937053 (FTO) & A & ADD & 1.57 & $0.94-2.59$ & 0.08 & 1.47 & $0.87-2.49$ & 0.15 \\
\hline rs2229616 (MC4R) & A & DOM & NA & NA & NA & NA & NA & NA \\
\hline rs7903146 (TCF7L2) & $\mathrm{T}$ & ADD & 1.11 & $0.65-1.89$ & 0.72 & 1.07 & $0.62-1.86$ & 0.81 \\
\hline \multicolumn{9}{|l|}{ Ischemic stroke } \\
\hline rs9937053 (FTO) & A & ADD & 1.03 & $0.82-1.29$ & 0.83 & 0.97 & $0.74-1.27$ & 0.84 \\
\hline rs2229616 (MC4R) & A & DOM & 1.19 & $0.52-2.72$ & 0.68 & 0.94 & $0.36-2.45$ & 0.90 \\
\hline rs7903146 (TCF7L2) & $\mathrm{T}$ & ADD & 0.95 & $0.75-1.21$ & 0.69 & 0.82 & $0.61-1.08$ & 0.15 \\
\hline \multicolumn{9}{|l|}{$\mathrm{ICH}$} \\
\hline rs9937053 (FTO) & A & ADD & 1.12 & $0.68-1.86$ & 0.65 & 1.10 & $0.64-1.9$ & 0.74 \\
\hline rs2229616 (MC4R) & A & DOM & 1.75 & $0.39-7.74$ & 0.46 & 1.47 & $0.32-6.74$ & 0.62 \\
\hline rs7903146 (TCF7L2) & $\mathrm{T}$ & ADD & 1.09 & $0.64-1.84$ & 0.76 & 1.07 & $0.63-1.82$ & 0.80 \\
\hline
\end{tabular}

$\mathrm{ADD}=$ Additive mode of inheritance $; \mathrm{DOM}=$ dominant mode of inheritance; $\mathrm{NA}=$ not available.

*Model 1: not adjust; crude estimates.

**Model 2: adjusted for age (years) and sex (female/male), history of hypertension (yes/no), history of diabetes (yes/no), physical inactivity (yes/no) and smoking (yes/no).

$\mathrm{p}=0.52$ ) and larger WHR (regression coefficient 0.003 , $\mathrm{p}=0.54$ ) for the obesity risk allele of the FTO polymorphism rs9937053).

The associations between variants of the three candidate genes and risk of stroke were investigated using logistic regression analysis (table 3 ). The ORs for stroke or TIA were 1.14 (95\% CI 0.91-1.42; $\mathrm{p}=0.25$ ) for FTO rs9937053 A-allele,
1.11 (95\% CI 0.49-2.51; $\mathrm{p}=0.80)$ for $M C 4 R$ V103I rs2229616 A-allele, 1.05 (95\% CI 0.82-1.34; $\mathrm{p}=0.72)$ for $M C 4 R$ variant rs17782313 C-allele, and 0.99 (95\% CI 0.78-1.25; $\mathrm{p}=0.92)$ for rs7903146 (TCF7L2). After adjustment (model 2) the observation of the absence of an effect was underlined. In addition, explorative stratification by sex did not show any significant sex-specific associations (table 3). 
Table 5. Sex-specific clinical outcome scores 7 days after stroke/TIA stratified by genotype

\begin{tabular}{|c|c|c|c|c|c|c|c|c|}
\hline \multirow[t]{2}{*}{ SNP (gene) } & \multicolumn{4}{|c|}{ mRS mean $($ median $) \pm \mathrm{SD}$} & \multicolumn{4}{|c|}{ NIHSS mean (median) \pm SD } \\
\hline & men & $\mathrm{p}$ value & women & p-value & men & $\mathrm{p}$ value & women & $\mathrm{p}$ value \\
\hline \multicolumn{9}{|c|}{ rs9937053 (FTO) } \\
\hline $\mathrm{TT}$ & $1.4(2) \pm 1.5$ & 0.22 & $2.7(2) \pm 2.6$ & 0.79 & $1.9(2) \pm 2.6$ & 0.24 & $5.3(3) \pm 5.7$ & 0.85 \\
\hline $\mathrm{AT}$ & $1.7(2) \pm 1.6$ & & $1.9(2) \pm 1.8$ & & $2.3(2) \pm 2.8$ & & $3.0(3) \pm 3.9$ & \\
\hline AA & $2.0(2) \pm 1.6$ & & $2.0(2) \pm 1.8$ & & $2.9(2) \pm 3.3$ & & $3.5(3) \pm 4.8$ & \\
\hline \multicolumn{9}{|c|}{ rs17782313 (MC4R) } \\
\hline $\mathrm{CC}$ & $1.9(2) \pm 1.8$ & 0.88 & $2.3(2) \pm 2.1$ & 0.67 & $3.0(3) \pm 3.3$ & 0.78 & $3.7(3) \pm 4.0$ & 0.80 \\
\hline $\mathrm{CT}$ & $1.8(2) \pm 1.7$ & & $1.8(2) \pm 1.7$ & & $2.7(3) \pm 3.4$ & & $2.8(3) \pm 3.5$ & \\
\hline TT & $1.7(2) \pm 1.5$ & & $2.1(2) \pm 1.8$ & & $2.2(3) \pm 2.7$ & & $3.6(3) \pm 4.6$ & \\
\hline \multicolumn{9}{|c|}{ rs2229616 (MC4R) } \\
\hline GG & $1.8(1) \pm 1.6$ & 0.58 & $2.1(2) \pm 1.8$ & 0.58 & $2.5(3) \pm 3.0$ & 0.50 & $3.6(2) \pm 4.5$ & 0.66 \\
\hline GA & $2.0(1) \pm 1.4$ & & $1.6(2) \pm 1.7$ & & $3.1(3) \pm 3.1$ & & $2.2(2) \pm 2.5$ & \\
\hline \multicolumn{9}{|c|}{ rs7903146 (TCF7L2) } \\
\hline $\mathrm{CC}$ & $1.5(1) \pm 1.4$ & 0.02 & $2.1(2) \pm 1.8$ & 0.61 & $2.0(2) \pm 2.5$ & 0.04 & $3.4(3) \pm 4.1$ & 0.34 \\
\hline $\mathrm{CT}$ & $2.1(2) \pm 1.7$ & & $2.1(2) \pm 1.9$ & & $3.1(3) \pm 3.2$ & & $3.4(3) \pm 4.9$ & \\
\hline $\mathrm{TT}$ & $1.9(2) \pm 1.7$ & & $1.4(2) \pm 1.6$ & & $3.1(3) \pm 4.0$ & & $2.3(3) \pm 1.7$ & \\
\hline
\end{tabular}

The analysis of different types of cerebrovascular disease showed a weak association of FTO rs9937053 A-allele with increased risk of TIA (OR 1.57, 95\% CI 0.94-2.59; $\mathrm{p}=0.08$ ) (table 4). The OR decreased after adjustment (1.47, 95\% CI $0.87-2.49 ; \mathrm{p}=0.15)$. For ischemic stroke and $\mathrm{ICH}$ no evidence for genetic associations was found.

Different genotypes were compared for association with stroke severity measured by NIHSS and mRS at admission and at follow-up on day 7 after admission. At admission, no differences in the stroke severity have been detected for the studied genotypes. The clinical outcome on day 7 was worse in male patients with allele $\mathrm{T}$ of rs7903146 (TCF7L2) compared to male patients with the $\mathrm{C}$ allele at this marker (mRS $\mathrm{p}=0.02$; NIHSS $\mathrm{p}=0.04$ ). There were no statistically significant differences in clinical outcome of female patients. The comparison of clinical outcomes by different genotypes related to FTO an MC4R did not provide evidence for statistically significant differences (table 5). We also did not find any associations between studied genotypes and the age at which the cerebrovascular event occurred (data not shown).

\section{Discussion}

We evaluated the confirmed variants in obesity and T2DM genes FTO, MC4R and TCF7L2 with regard to their potential role in the risk of stroke/TIA. Obesity is an important vascular risk factor and its role in stroke has been intensely investigated in the last years [27]. For example, we have reported an association between abdominal obesity and increased risk of stroke/TIA [8] which has been replicated in two populationbased studies $[6,7]$.
Large-scale studies searched for candidate genes for obesity and found associations with common genetic variants of the genes FTO and MC4R [17, 19, 21]. The minor (A) allele of the most common intragenic variant of $M C 4 R$ (rs2229616) was shown to be associated with decreased BMI [28]. The role of $M C 4 R$ as genetic risk factor contributing to the development of other common risk factors of cerebrovascular disease (e.g. insulin resistance and metabolic syndrome) was discussed in the recent years [21, 29]. However, genetic studies have so far not evaluated the association between $M C 4 R$ and the risk of cerebrovascular disease outcomes directly. Despite the evidence from previous studies on the association of $M C 4 R$ with cerebrovascular risk factors, the variant rs2229616 was not associated with risk of stroke/TIA in the present study.

FTO has also been shown to be associated with obesity and other cerebrovascular risk factors such as the metabolic syndrome [30], and a possible role in atherosclerosis is under discussion. Kivimaki et al. [31] showed that individuals with the A allele of the FTO polymorphism rs9939609 had a trend towards increased intima-media thickness of the carotid artery, which is a clinical marker of atherosclerosis. To the best of our knowledge, none of previous studies evaluated the FTO variants with a focus on cerebrovascular disease. Our study did not observe any evidence for an association between $F T O$ and risk of stroke. Interestingly, we found a weak association between FTO rs9939609 and risk of TIA. Therefore, further studies should focus on evaluation of rs9939609 in risk of TIA.

$\mathrm{T} 2 \mathrm{DM}$ is one of the most important risk factors for cerebrovascular disease $[20,32]$. The TCF7L2 polymorphism rs7903146 has been consistently associated with T2DM in dif- 
ferent populations [33]. In addition, the same variant has been reported to be associated with obesity and the severity and mortality of cardiovascular disease [23]. However, data on its role in vascular diseases are inconsistent [34]. We observed that allele $\mathrm{T}$ of TCF7L2 showed a positive association with T2DM which is consistent with the results of previous studies [33]. However, we did not observe any evidence for an association between TCF7L2 and risk of stroke.

Little is known about the genetic determinants of outcome after stroke. The associations with survival and disability following stroke were found for genotypes of interleukin-1 receptor antagonist, interleukin-6, and insulin-like growth factor I [35-37]. Currently, genetic determinants of stroke outcome are being investigated in the Genes Affecting Stroke Risk and Outcome Study (GASROS) [38]. Our study found a sex-specific influence of the $\mathrm{T}$ allele of TCF7L2 on the functional outcome after stroke measured by both mRS and NIHSS. This corresponds with data from other stroke studies showing that hyperglycemia is associated with a poor clinical outcome in stroke patients [39].

Strengths of our study are that we used a case-control design with controls ascertained from a population-based study. Cases were recruited consecutively in two large neurological clinics with a well-defined catchment area of approximately 800,000 inhabitants. The moderate sample size of our study is comparable to the samples sizes of other genetic studies in stroke (549 cases in the ARIC study [34], 540 cases in the Rotterdam Study [40], 297 cases in the Stroke Prevention in Young Women Study [41]). However, this study did not have sufficient statistic power to identify ORs for stroke that are in the order of 1.2 or lower and should be considered as a pilot study on the role of obesity genes (FTO, MC4R, and TCF7L2) in the risk of common stroke. In order to substantiate the possible association between FTO and the risk of stroke/TIA, a sample size of at least about 3,000 case-control pairs as based on the observed effect (OR 1.1) and allele frequency $(\sim 40 \%)$ would be necessary for a power of $80 \%$. As case-control studies focusing on stroke with such a sample size are rare, future meta-analyses will be necessary to address the question of potential smaller effects of the three investigated markers of the three genes FTO, MC4R and TCF7L2 on the risk of stroke or
TIA. Additionally, very severely affected patients or patients with global aphasia were not included in this study as their informed consent could not be obtained. This may have limited the number of severe strokes so that these are underrepresented. There were only individuals aged 45-75 years among the controls; so exact age matching was not possible. In order to avoid a systematic error of data, the plausibility proof was conducted by using only the exact age match for cases aged 45-75 years. This analysis confirmed all main results as robust [8]. Finally, we evaluated only three candidate genes of obesity and T2DM for their impact on stroke/TIA. $M C 4 R$ and FTO are the most important obesity genes at the time of the study conduct $[17,19,21]$, whereas TCF7L2 is the most important genetic factor for T2DM. In or near the above mentioned candidate genes, we evaluated alleles of SNPs, which are known to be robustly associated with obesity or T2DM susceptibility despite the fact that these variants may not be the variants with a functional effect. Currently, a number of new candidate genes are suggested that may come under investigation soon [42, 43].

In conclusion, we evaluated variants of three candidate genes for obesity and T2DM, MC4R, FTO and TCF7L2, for a potential contribution to stroke susceptibility and observed no significant associations. In an explorative, sex-stratified analysis, we observed a weak association of the $\mathrm{T}$ allele of TCF7L2 to clinical outcomes which requires replication. Future studies on genetics of common stroke should concentrate on evaluation of genes predisposing to cerebrovascular risk factors, such as obesity and T2DM, and consider the assessment of genetic determinants of clinical outcome.

\section{Acknowledgments}

The Mannheim-Heidelberg Stroke Study was funded by the German Ministry of Education and Research (BMBF)/National Genome Research Network (NGFN), research grant 01GS0491 (project leader: Prof. Tobias Back), grand 01GS0820.

\section{Disclosure Statement}

The authors declare that they have no competing interests.

\section{References}

$>_{1}$ Winter Y, Wolfram C, Schaeg M, Reese JP, Oertel WH, Dodel R, Back T: Evaluation of costs and outcome in cardioembolic stroke or TIA. J Neurol 2009;256:954-963.

2 Winter Y, Wolfram C, Schöffski O, Dodel RC, Back T: Long-term disease-related costs 4 years after stroke or TIA in Germany (in German). Nervenarzt 2008;79:918-926.
3 Epifanov Y, Dodel R, Haacke C, Schaeg M, Schoeffski O, Hennerici M, Back T: Costs of acute stroke care on regular neurological wards: a comparison with stroke unit setting. Health Policy 2007; 81:339-349.

4 Back T, Schaeg M, Back C, Epifanov Y, Hemmen T, Dodel RC, Schoffski O: Costs of stroke unit care in Germany. Resource use and reimbursements by German diagnosis related groups (in German). Nervenarzt 2004;75:991-999.
5 Dodel R, Winter Y, Ringel F, Spottke A, Gharevi N, Muller I, Klockgether T, Schramm J, Urbach H, Meyer B: Cost of illness in subarachnoid hemorrhage. A German longitudinal study. Stroke 2010; 41:2918-2923.

6 Suk SH, Sacco RL, Boden-Albala B, Cheun JF, Pittman JG, Elkind MS, Paik MC: Abdominal obesity and risk of ischemic stroke: the Northern Manhattan Stroke Study. Stroke 2003;34:1586-1592. 
7 Hu G, Tuomilehto J, Silventoinen K, Sarti C, Mannisto S, Jousilahti P: Body mass index, waist circumference, and waist-hip ratio on the risk of total and type-specific stroke. Arch Intern Med 2007; 167:1420-1427.

8 Winter Y, Rohrmann S, Linseisen J, Lanczik O, Ringleb PA, Hebebrand J, Back T: Contribution of obesity and abdominal fat mass to risk of stroke and transient ischemic attacks. Stroke 2008;39: 3145-3151.

9 Dichgans M: Genetics of ischaemic stroke. Lancet Neurol 2007;6:149-161.

10 Casas JP, Hingorani AD, Bautista LE, Sharma P. Meta-analysis of genetic studies in ischemic stroke: thirty-two genes involving approximately 18,000 cases and 58,000 controls. Arch Neurol 2004;61: 1652-1661.

11 Lee BC, Lee HJ, Chung JH: Peroxisome proliferator-activated receptor-gamma2 Pro12Ala polymorphism is associated with reduced risk for ischemic stroke with type 2 diabetes. Neurosci Lett 2006; 410:141-145.

12 Zafarmand MH, van der Schouw YT, Grobbee DE, de Leeuw PW, Bots ML: Peroxisome proliferator-activated receptor gamma-2 P12A polymorphism and risk of acute myocardial infarction, coronary heart disease and ischemic stroke: a casecohort study and meta-analyses. Vasc Health Risk Manag 2008;4:427-436.

13 Hermann S, Rohrmann S, Linseisen J: Lifestyle factors, obesity and the risk of colorectal adenomas in EPIC-Heidelberg. Cancer Causes Control 2009;20:1397-1408.

14 WHO MONICA Project Principal Investigators: The World Health Organization MONICA Project (monitoring trends in cardiovascular disease): a major international collaboration. J Clin Epidemiol 1988;41:105-114.

15 Rankin J: Cerebral vascular accidents in patients over the age of 60. Scott Med J 1957;2:200-215.

-16 Brott T, Adams HP Jr, Olinger CP, et al: Measurements of acute cerebral infarction: a clinical examination scale. Stroke 1989;20:864-870.

17 Loos RJ, Lindgren CM, Li S,: Common variants near $M C 4 R$ are associated with fat mass, weight and risk of obesity. Nat Genet 2008;40:768-775.

18 Geller F, Reichwald K, Dempfle A, Illig T, Vollmert C, Herpertz S, Siffert W, Platzer M, Hess C, Gudermann T, Biebermann H, Wichmann HE, Schafer H, Hinney A, Hebebrand J: Melanocortin-4 receptor gene variant I103 is negatively associated with obesity. Am J Hum Genet 2004;74:572-581.

19 Frayling TM, Timpson NJ, Weedon MN, et al: A common variant in the FTO gene is associated with body mass index and predisposes to childhood and adult obesity. Science 2007;316:889-894.

20 Grant SF, Thorleifsson G, Reynisdottir I, et al: Variant of transcription factor 7-like 2 (TCF7L2) gene confers risk of type 2 diabetes. Nat Genet 2006; 38:320-323.

21 Chambers JC, Elliott P, Zabaneh D, Zhang W, Li Y, Froguel P, Balding D, Scott J, Kooner JS: Common genetic variation near $M C 4 R$ is associated with waist circumference and insulin resistance. Nat Genet 2008;40:716-718.
22 Helgason A, Pálsson S, Thorleifsson G, et al: Refining the impact of TCF7L2 gene variants on type 2 diabetes and adaptive evolution. Nat Genet 2007; 39:218-225.

23 Sousa AG, Marquezine GF, Lemos PA, Martinez E, Lopes N, Hueb WA, Krieger JE, Pereira AC: TCF7L2 polymorphism rs7903146 is associated with coronary artery disease severity and mortality. PloS One 2009;4(11):e7697.

24 Muller TD, Hinney A, Scherag A, Nguyen TT, Schreiner F, Schafer H, Hebebrand J, Roth CL, Reinehr T: 'Fat mass and obesity associated' gene $(F T O)$ : no significant association of variant rs9939609 with weight loss in a lifestyle intervention and lipid metabolism markers in German obese children and adolescents. BMC Med Genet 2008;9:85.

25 Roth CL, Hinney A, Reinehr T, Schreiner F, Nguyen TT, Muller T, Scholl C, Woelfle J, Karpushova A, Schafer H, Nothen MM, Hebebrand J: TCF7L2 polymorphism rs7903146 and predisposition for type 2 diabetes mellitus in obese children. Horm Metab Res 2008;40:713-717.

26 Gotoda T, Scott J, Aitman TJ: Molecular screening of the human melanocortin-4 receptor gene: identification of a missense variant showing no association with obesity, plasma glucose, or insulin. Diabetologia 1997;40:976-979.

27 Yusuf S, Hawken S, Ônpuu S, Bautista L, Franzosi MG, Commerford P, Lang CC, Rumboldt Z, Onen CL, Lisheng L, Tanomsup S, Wangai JP, Razak F, Sharma AM, Anand SS, on behalf of the INTERHEART Study Investigators: Obesity and the risk of myocardial infarction in 27000 participants from 52 countries: a case-control study. Lancet 2005;366:1640-1649.

28 Dempfle A, Hinney A, Heinzel-Gutenbrunner M, Raab M, Geller F, Gudermann T, Schafer H, Hebebrand J: Large quantitative effect of melanocortin-4 receptor gene mutations on body mass index. J Med Genet 2004:41:795-800.

29 Heid IM, Vollmert C, Kronenberg F, Huth C, Ankerst DP, Luchner A, Hinney A, Bronner G, Wichmann HE, Illig T, Doring A, Hebebrand J: Association of the MC4R V103I polymorphism with the metabolic syndrome: the KORA Study. Obesity (Silver Spring) 2008;16:369-376.

30 Al-Attar SA, Pollex RL, Ban MR, Young TK, Bjerregaard P, Anand SS, Yusuf S, Zinman B, Harris SB, Hanley AJ, Connelly PW, Huff MW, Hegele RA: Association between the FTO rs9939609 polymorphism and the metabolic syndrome in a non-Caucasian multi-ethnic sample. Cardiovasc Diabetol 2008;7:5.

31 Kivimaki M, Smith GD, Timpson NJ, Lawlor DA, Batty GD, Kahonen M, Juonala M, Ronnemaa T, Viikari JS, Lehtimaki T, Raitakari OT: Lifetime body mass index and later atherosclerosis risk in young adults: examining causal links using Mendelian randomization in the Cardiovascular Risk in Young Finns study. Eur Heart J 2008;29:2552-2560.
32 Groves CJ, Zeggini E, Minton J, Frayling TM, Weedon MN, Rayner NW, Hitman GA, Walker M, Wiltshire S, Hattersley AT, McCarthy MI: Association analysis of 6,736 U.K. subjects provides replication and confirms $T C F 7 L 2$ as a type 2 diabetes susceptibility gene with a substantial effect on individual risk. Diabetes 2006;55:2640-2644.

33 Cauchi S, El Achhab Y, Choquet H, Dina C, Krempler F, Weitgasser R, Nejjari C, Patsch W, Chikri M, Meyre D, Froguel P: TCF7L2 is reproducibly associated with type 2 diabetes in various ethnic groups: a global meta-analysis. J Mol Med (Berl) 2007;85:777-782.

34 Bielinski SJ, Pankow JS, Folsom AR, North KE, Boerwinkle E: TCF7L2 single nucleotide polymorphisms, cardiovascular disease and all-cause mortality: the Atherosclerosis Risk in Communities (ARIC) study. Diabetologia 2008;51:968-970.

35 Gromadzka G, Sarzynska-Dlugosz I, Czlonkowska A: ILIRN intron 2 polymorphism caused by variable number tandem repeats is associated with 1-year outcome in patients with ischaemic stroke. J Neurol Neurosurg Psychiatry 2007;78:183-186.

36 Greisenegger S, Endler G, Haering D, Schillinger M, Lang W, Lalouschek W, Mannhalter C: The (-174) G/C polymorphism in the interleukin-6 gene is associated with the severity of acute cerebrovascular events. Thromb Res 2003;110:181-186.

37 van Rijn MJ, Slooter AJ, Bos MJ, Catarino CF, Koudstaal PJ, Hofman A, Breteler MM, van Duijn CM: Insulin-like growth factor I promoter polymorphism, risk of stroke, and survival after stroke: the Rotterdam study. J Neurol Neurosurg Psychiatry 2006;77:24-27.

38 Ramoni RB, Himes BE, Sale MM, Furie KL, Ramoni MF: Predictive genomics of cardioembolic stroke. Stroke 2009;40(3 suppl):S67-70.

39 Kruyt ND, Biessels GJ, Devries JH, Roos YB: Hyperglycemia in acute ischemic stroke: pathophysiology and clinical management. Nat Rev Neurol 2010;6:145-155.

40 Sie MP, Uitterlinden AG, Bos MJ, Arp PP, Breteler MM, Koudstaal PJ, Pols HA, Hofman A, van Duijn CM, Witteman JC: TGF-beta 1 polymorphisms and risk of myocardial infarction and stroke: the Rotterdam Study. Stroke 2006;37:2667-2671.

41 MacClellan LR, Howard TD, Cole JW, Stine OC Giles WH, O'Connell JR, Wozniak MA, Stern BJ, Mitchell BD, Kittner SJ: Relation of candidate genes that encode for endothelial function to migraine and stroke: the Stroke Prevention in Young Women study. Stroke 2009;40(10):e550-557.

42 Speliotes EK, Willer CJ, Berndt SI, et al: Association analyses of 249,796 individuals reveal 18 new loci associated with body mass index. Nat Genet 2010;42:937-948.

43 Heid IM, Jackson AU, Randall JC, et al: Metaanalysis identifies 13 new loci associated with waist-hip ratio and reveals sexual dimorphism in the genetic basis of fat distribution. Nat Genet 2010;42:949-960. 